\title{
Making the Hetch-Hetchy Dam Itself
}

\section{How California's Big Water Development Is Carried On with Its Own Water}

By J. F. Springer

ARGE engineering works often involve subsidiary 1 constructions of considerable size whose primary function is merely to promote the main operations. Thus, in the great Hetch-Hetchy enterprise, which is uitimately to supply San Francisco with $400,000,000$ gallons of water per day or whatever part of this immense amount will be needed, it has become advisable not only to build motor truck roads but to construct a standard bage railroad 68 miles long. Another large subsidiary malertaking is the power station which is to supply electric energ for the operation of powe driven appliances which are to be engaged upon the construction of the great Hetch-Hetchy Dam, one of the main features of the whole enterprise, and of an 18-mile tunnel of the main aqueduct.

The power development is for construction purposesat least primarily. The water for it comes from the beautiful Lake Eleanor whose outlet has been dammed by a multiple arch dam and whose area and impounding capacity have been thus increased. Lake Eleanor is at a considerably higher elevation than the power house and the difference in level is by no means all used in providing the hydrostatic head back of the pressure water entering the turbines. The bed of
The power house is 12 miles distant from the site of Hetch-Hetchy Dam. Naturally, this dam is the means of impounding the water of Hetch-Hetchy Reservoir. This dam and reservoir are also, like Eleanor Dam and Lake, farther up in the mountains than the power development under consideration. The great dam is, however, at an elevation considerably lower than the smaller one. Hetch-Hetchy Reservoir will discharge its vaste into the Tuolumne River. The water for San Fraste into the Tuover be deliver water for Srancisco will, however, be delivered to a the supply down along a line roughly parallel to the Tuolumne River on one side and the Hetch-Hetchy Railroad on the other. This tunnel will be 12 miles in length and will deliver its water to a great power house. After passing through this station, the water will enter a long stretch of tunnel. Whenever the water from Lake Eleanor is to be sent on to San Francisco, it will naturally he passed into this long tunnel as well as that from Hetch-Hetchy Reservoir. This tunnel will be 18 miles long and will extend form. Early Intake, near hoth the power houses already mentioned, to Priest Regulating Reservoir. The Cherry River power station supplies current for construction
The portal at Early Intake is far below the level of The portal at Early in the material delivered here has to be lowered. This is accomplished by means of an inclined tramway 3,800 feet long. An electric hoist is located at the upper terminus and supplies the powe for operation. The steepness of parts of the incline may be judged by the fact that the grades run up to $78^{\circ}$. There is also another tramway at the portal 18 miles farther down the line at Priest. This is a counterbalanced affair and is used to lower supplies from the railroad. Construction plants have been set up at the termini, at the crossing of South Fork and at two shafts in intermediate locations. Standard mining equipment has been given the preference when providing these plants, one object being to reduce the cost of repairs and the amount of spare parts that would need to be carried in stock. Among the appliances in use are motor-driven air compressors, rotary blowers, storage battery locomotives, side-dump tunnel cars provided with roller bearings, rock drills, etc. A mucking machine has been in satisfactory use in the tunnel heading from the Priest portal. This machine secures the spoil from the blasting operations at the heading, elevates it and delivers to tunnel cars. The

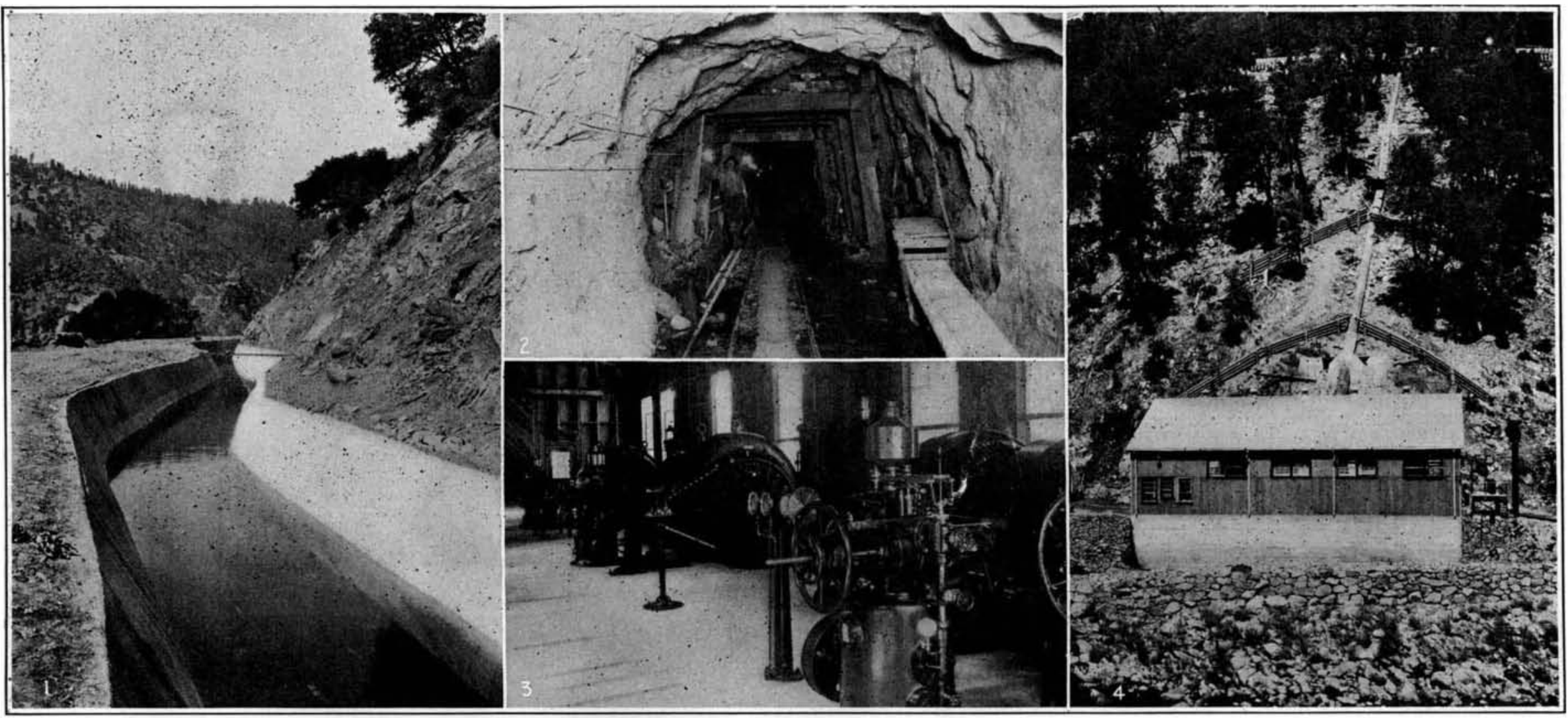

1. View of the aqueduct at Early Intake. 2. Interior of the South Fork Tunnel. 3. Power house at Early Intake, 4. The timber flume that brings the water to the power house Some of the work in connection with the subsidiary construction of power houses on the Hetch-Hetchy project

the Eleanor Creek at the site of the dam is 2,347 feet higher up in the mountains than is the power station. The water rushes down Eleanor Creek and into the Cherry River. At a point on this stream some $31 / 2$ miles from the power house, a dam has been constructed whose function it is to divert sufficient water from Cherry River to operate the turbines. This diversion dam diverts the water into a channel or conduit. From this the water flows into a steel penstock which runs down a steep incline. The capacity of the which runs down a steep incline. The capacity of the canal is 200 second-feet. This part of the construction with concrete: one mile of the total is devoted to flve with concrete; one mile of the total is devoted to flve
tunnels; and $11 / 2$ miles in all to three flumes. While tunnels; and $11 / 2$ miles in all to three flumes. While
the canal is lined, the tunnels are not, except at por tals and a few scattering locations. The construction of the tunnels has proven pretty hard work, as the rock formation is of granite. However, rock spoil derived from the tunnels was found useful as coarse aggregate for concrete work. The flumes were constructed of wood. The minimum section is $5 \times 61 / 2$ feet. Ultimately, this temporary construction is to be replaced by rock tunnels. The concreted canal and Lake Eleanor Dam are to be retained as permanen parts of the general work. purposes on this great tunnel. There are two large pieces of work which this power house is to care for, one being the tunnel and the other the great dam. Its location is well adapted to serve both. The most distant point of the tunnel will be at its lower end some 18 miles away in the direction of San Francisco. The big dam is 12 miles distant in the opposite direction.

The tunnel to Priest may be divided into two sections. The one nearer Early Intake is perhaps 6 miles long and has a great mass of rock overhead. The other section is some 12 miles long and is farther down the line. It is also covered with a great mass of rock. The point of junction, however, where the one terminates and the other begins is in the bottom of a big ravine where the south fork of the Tuolumne River cuts across the line of the aqueduct. The entire 18 miles of tunne may be viewed as a single section of downgrade of unvarying inclination. The tunnel diameter is $10^{1 / 4}$ feet and the difference in level between terminal portals is 150 feet. The capacity of this tunnel is necessarily, at least equal in amount to the contemplated delivery at San Francisco. There are in all four portals, two being intermediate The Hetch-Hetchy Railroad touches practically all of them. This is important in the matter of prosecuting construction. use of a machine for this work in a considerable tunnel in hard rock is understood to be rated as more or less experimental. It is thought, however, to have been advantageous here in view of the shortage of labor.

At the two shafts, there are naturally two headings per shaft. Duplicate equipment was supplied in order to permit rapid work on both. One of the shafts is known as Big Creek shaft Before 1919 had closed, this shaft had been carried down to its full depth of 646 feet and chambers at and below tunnel grade had been excavated at its foot. These chambers were starting points for the headings. A rather unusual method of handling the water was employed on this shaft. When the excavation had got down nearly half way, a considerable flow of water entered the shaft; but lower down the flow moderated. A method usual in shaft sinking proceeds by arranging a sump in the bottom of the excavation and pumping the water up from this lever. Here, this would have meant, when large part of the water from twice the depth at which it en part a pumping station with sump was constructed and all water from upper levels intercepted and pumped out. (Continued on page 497) 


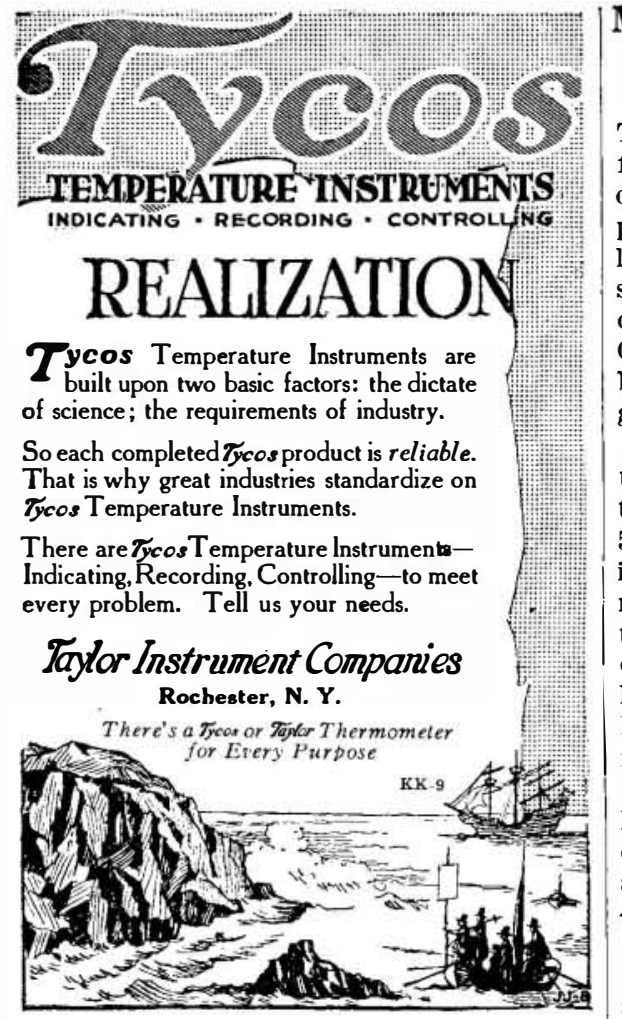

Friction Disk Drill FOR LIGHT WORK

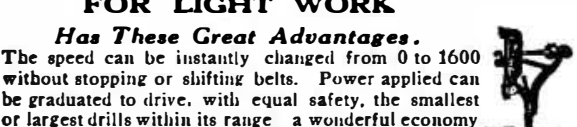
or largest trills within its range a wounder

W. F. \& Jno. Barnes Company 1999 Ruby Street Established 1872

POWER BENDERS NEWMODELS $_{\text {TWO }}$

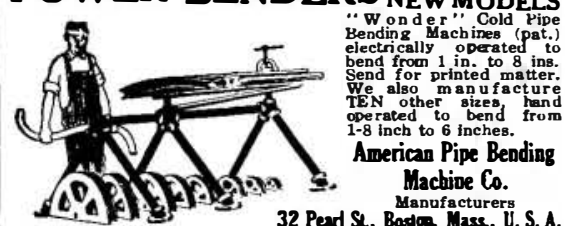

THESCHWERDTLE STAMP CO. SIEEL STANPS LETTERS \& FIGURES BRIOGEPORT CONN.
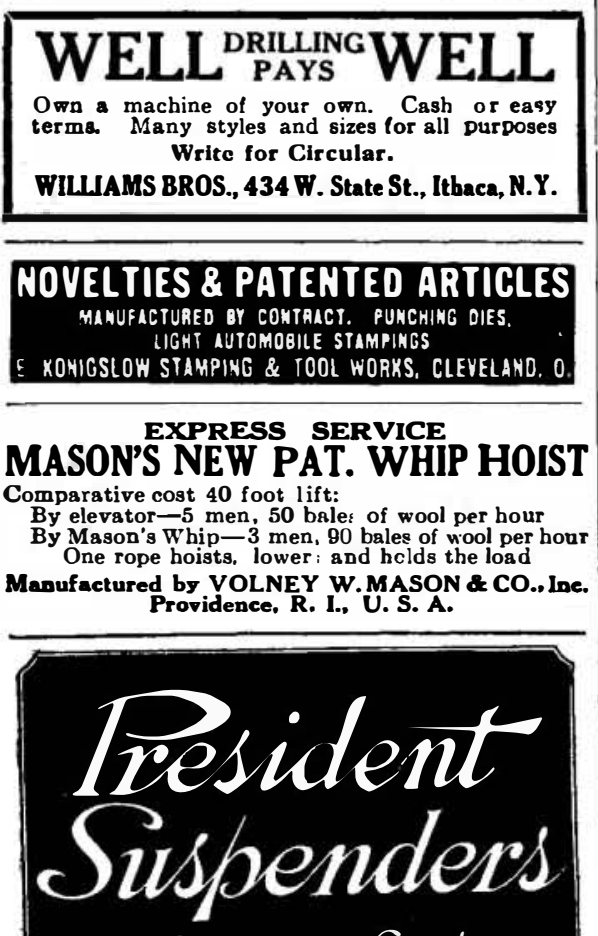

fòr comfort

Every pair giuaranteed

MADE AT SHIRLEY MASSACHUSETTS
Making the Hetch-Hetchy Dam Itself

(Continued from page 422)

The tunnel level is really some distance fiom the very bottom, being at a depth of 575 feet. The excess depth of the shaft provides for a special pocket equipped to oad skips by gravity and for a pumping sump. Another shaft providing for access to the tunnel is known as the Second Garrotte shaft. Its full depth is, or will be, about 820 feet, though the tunnel grade is only 756 feet below the surface. In driving the headings, a round of 18 to 24 blasting holes is provided. When these are exploded, an adrance of about 5 feet is made. The excavation is made in full section at single operations, so that tunnel is ultimately to be lined with con. crete. The minimum thickness of the lining is 6 inches. The cross-section is of horse-shoe shape, the toe of the shoe being naturally at the top.

The power house which is located at Early Intake and whose pressure water comes from Lake Eleanor operates under a head of 346 feet and has a capacity of $4,000 \mathrm{hp}$. The use of timber flumes as part of the conduit which brings water from the diversion dam on Cherry River seems to have been dictated largely by the consideration that upon certain very precipitous mountain sides it would have been exceedingly expensive to excavate for a concrete canal. Later on, when conditions are more favorable, it is proposed to replace the flumes by tunnels, and to provide the necessary cross-cuts. The tunnel work may then be done without interruption to the operation of the plant. The manner of constructing the flumes on the steep mountain sides is of interest. A certain amount of excavation done in order to provide for the support of the footings. This was carried to bed rock. The under part of the framing was put in place and the floor laid. A track was constructed of wooden rails and push cars loaded with lumber were shoved along on it. An immense amount of lumher was consumed-upward of $1,300,000$ board-feet. The city cut this lumber at its own saw-mill, from which it went to the points of use.

The steel penstock is 42 inches in diameter. From the forebay down to the turbines which it serves, it is 530 feet long. inch to twice as much Naturally, the heavier wall is used in the lower sections, where the hydrostatic head runs up to a maxithe hydrostatic head runs up to a maxi-
mum pressure in the neighborhood of 150 mum pressure in the neighborhood of 150
pounds per square inch. The wheels are pounds per square inch. The wheels are Pelton-Francis turbines operating in vertical planes. They are direct-connected to their respective generators. The current is developed at 2,300 volts, but is stepped up to 22,000 for transmission purposes. The lines are estimated to extend 19 miles on the west and 14 on the east. There are three units, although the plans called for the output of but two, the third called for the output of but two, the third
being reserved for emergency use. The being reserved for emergency use. The
transmission line to the west lies in the transmission line to the west lies in the same vertical plane with the tunnel underneath.

The Farly Intake power house performed a certain amount of service during the fuel shortage of the Great War. It began operation as early as May, 1918, at a time when its full capacity was not required for aqueduct work. In September, the Power Administrator ordered that the transmission line be connected with that of the Sierra \& San Francisco Power Company for the purpose of supplying surplus energy at points served by this commercial concern. In three days after the date of the formal order, the connection had been made and the delivery of surplus energy begun. In fact during the fiscal year 1918-1919, of the total output of $18,687,400 \mathrm{kw}$.-hrs., $13,505,621 \mathrm{kw}$. hrs. were delivered for use other than that connected with the aqueduct.

The muck handling machine already

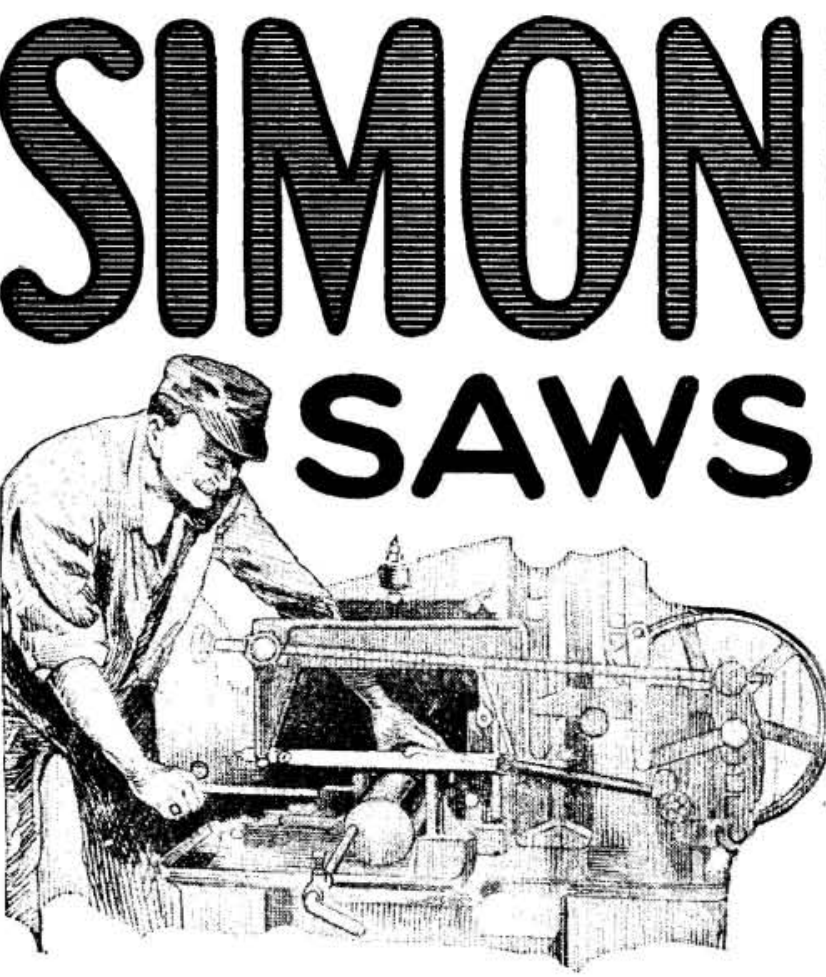

\section{Hack Saw Blades}

Simonds-Made Hack Saw Blades are the most economical to use: they cut with less resistance, remove no more metal than necessary, and wear the longest.

This superior saw service is primarily due to the Simonds Steel that's put into these blades. It is a steel especially made and toughened for hard cutting service by an exclusively Simonds process developed in their own Crucible Steel Mill.

There is a SIMONDS way to cut steel, wood, paper, ice, leather, cork, rags, etc.

Write for Simonds booklet-“Methods of Cutting Metal."

\section{Simonds Manufacturing Company}

$$
\text { "The Saw Makers" Eatablished } 1832
$$

Fitchburg, Massachusetts

$\begin{array}{lll}\text { Chicago, lll. } & \text { New York City } & \text { New Orleans La } \\ \text { Lockport, N. Y. } & \text { Memphis, Tenn. } & \text { London, England } \\ \text { Portland, Ore. } & \text { Vancouver, B. C. } & \text { Montreal, Oue. }\end{array}$

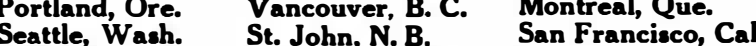

